Dr. S.A. Swanepoel

Department of Bantu Languages

OPENING AND CLOSING FORMULAE IN TSWANA FOLKTALES: A STRUCTURAL AND FUNCTIONAL ANALYSIS

\title{
1:0 Introduction
}

Opening and closing formulac are acknowledged by many research wor kers and specialists of folktales. It is herefore a pity that although most rescarchers have recognized it, here is a tendency to neglect the layout of the structure and the functions played by the formulac. In this discussion attention will be paid to the structure and the various functions of the formulac, because the opening and closing formulac, as a unity, contstitute one of the main structural features of folktales.

\subsection{Opening formulae}

\subsection{Hat is an operning formula?}

An opening formulac can be described as a sentence or sentences used to open a folktale and as such to announce the onset of the tale itself.

Example:

Ga te ckilê ya re bogologolo ga bô go na le l'hiri le Phokojê le Pela

It is said that a long time ago, there were a hyena, a jackal and a rorkrabbit.

\subsection{Recent acknoteledyements of the opening formula}

The following researchers have paid attention or recognized the opening formula in their study of folktales: Mbiti (1966:26) states that a folktale can be started by using several forms of opening formulac. He inentions that narrators can implement formulac of their own choice. According to Guma (1967:33) the following is the form that is used most commonly in Southern Soho folktales:

Ba re e nê e re...

'They say it happened that ...

He also mentions the fact that the gencral form is sulyect to variation and that the folktale commenees immediately after the opening formula has bern announced. Finnegan (1967:85-86, 1970:379) deals with the sulyject in her study of Jimba stories and also her book which covers oral literature 
in Ariea. She rengnizes the formula and points out the fact that even the audience can take pant in the opening process and therefore slimulate the telling of folktales. Srlueul, (1975:9) mentions the formula and st ipulates the following opening lormulae for Xhosa:

Kwathe ka kalokhu ngantsomi ...

Ku'a suka-sukicle...

Yathinlsumi ...

Kwahla kwa-inlsomi ...

Marivate (197:3:31) calls the opening formula an "operat ive phrase" in his sludy of l'songa lolktales. He, like Finnegan, states the fact that the audience takes part in the process.

Necthling (1979: 172-196) makes an cflort to find a st andardized form for the lommla by giving a list of the formular which occur in the dat a collected for his thesis. He recognizes the other formulac which difler fiom the standaudized form as variants of the original form. He states the following example as the standardized form for Xhosa:

Kwathi ke kalokhu ngantsomi ...

( )ul of 45 lolk ales which he collected, 16 make use of the standardized form, while the others are variant forms. Neethling's main contribut ion lies in the fact that he recognizes the opening formula as a structural clement in the folktale.

2.3 Afin these vimeproints have been studied, the followeing conslusions can be draten:

- the opening formula is recognized by all researchers;

- several fiums of the formula are recognized;

- rertain formular occur more frequently than others;

- sometimes the audience takes part in implementing the formulac.

2.1 Oprening.formulae in T swana folktales

All 'Tswatua folktales commence with an operning formula. For a mcaningful discussion of the opening formula, it is cecciled to distinguish between a full form and its monim/s. This viewpoint accommorlates a more scicntilic way of dealing wish the opening formulac. $\Lambda$ syntactical and morphological analysis constiutes the following for 'I'swana:

i. Indefinile subjeretival concord ga plus the verb re/say;

ii. a noun as subject; 
iii. definite or indefinite subjectival concord plus auxiliary verb kilêe/rilê;

iv. definite or indefinite subjectival concord plus re;

v. temporal adverb;

vi. a noun as subject;

vii. a associative or identifying copulative -na le/le;

viii. a noun subject; and

ix. a verb plus object and adverb.

This full form, as stipulated above, accommodates all the opening formulae distinguished for Tswana. In certain instances some of the elements are clided and the formula can thus be seen as a variant form of the full form. A further characteristic of the formula, is the set order which the elements' maintain. Each narrator chooses the opening formula for his particular folktale out of his full form. This fixed order causes the opening formula to show a standardized form. The following are examples collected during fieldwork done amongst the Tswana people:

\section{Full form}

Ga te + noun + kilê + re + temp.adv. + noun + ass. $/$ id.cop. + noun + verb.

\section{Variants}

Ga te $+\ldots+$ + e kilê + ya re + bogologolo $+\ldots+$ ga bô go na le + Phiri le +

Phokoje le

Pela

Ga te $+\ldots+$ e kilê + ya re + $+$ + e le + Tselane

le +

mmaagwe

Monna le + $+$ $+\ldots+$ + ga bó go na le + mosadi

Gate + Tau le + $+$ + e rilê + ka nako + ê nngwe + ga bó go na le +

Mmutlê

Ga te + badisa + ba kilê + $+$ $+$ $+$ + ba kópana. 
Included in the opening formulac is the following esscntial information:

- lime suggestion (long ago);

- the introduction of the leading characters in the folktale; and

- circumstances that form the background.

Examples: Ga tc c rilck ka nako $\hat{c}$ nngwe ga bo go na le ...

It is said that once upon a time there were ...

Tau le Mmule ...

I.ion and Rabbit ...

Ga te c kilĉ ya re e le ...

It is said that there was...

Mosetsana ...

A girl ...

A se na mmaagwe ...

Who did not have a mother...

No evidence has been found that the audience participates in the opening of the folktale.

\subsection{CLOSING FORMULAE}

\subsection{What is a closing formula?}

The closing formula consists of a short phrase that is used to end the folktale.

Example: 'T'sa bê di hêla!

It came to an end!

\subsection{Recent acknowledgements of the closing formula}

Closing formulac are also generally acknowledged in the various studies of folktales, but as is the case with the opening formulae, little attention has been paid to in-depth study of the element and basically the subject is only mentioned by the ditlerent rescarches.

Examples:

Mbiti (I966:29) only states that there are several formular for the closing of 
Akamba storics. According to Guma (1967, p. 33-34) the closing formula appears to be "a fixed formula". The Southern Sotho folktales usually end in this way:

Ke tshomo ka mathetho.

It is the end of the story.

Finnegan (1970:87) has accertained that the closing formulae show a more fixed structure than the opening formulae, and therefore display a restricted character. This character is found in Xhosa folkt ales which are traditionally ended by these formulae. Scheub (1970:13) quotes the following for Xhosa:

Phela phela ngantsomi!

Phola!

After having implemented a frequency test, Neethling (1970:177-180) stipulates the structure which is most commonly used in Xhosa. He too mentioned the fixed character of this formula.

Marivate (1973:56) mentions the role played by the audience in the ending of "Tsonga folktales. He calls it "the killing of the tale".

3.3 The following conclusions can be drawn after studying the above viewpoints:

- closing formulac are generally acknowledged; and

- the formulae are used to end a folktale and show a more fixed form than the opening formulae.

\subsection{Closing formulae in Tswana folktales}

Tswana folktales are always ended by using a closing fornula. This formula is implemented by the narrator and no evidence has been found of the audience taking part in the process. The formulac show, as is the case in other languages, little variation. By means of a syntactical and grammatical analysis, a full form and its variants can be identified. The full form is constructed by the following:

i. Definite subjectival concord of the di-class plus auxilliary verlss $b a / b \hat{o} / b \hat{e}$;

ii. definite subjectival concord of the di-class plus the verbs/ela/felêa; and iii. a locative adverb $f a / f a o$. 
All the variants are dirived from this full form. The elements in the formulae are always restricted to the same order, and thus reflect a bounded form, which sulsequently displays very little variation. Examples of closing formulac:

Finll form:

$$
\begin{aligned}
& \text { subjectival }+ \text { ba/be } / \text { bo }+ \text { subjectival }+ \text { fèla }+f a / f a o \\
& \text { concord concord fêlêla } \\
& \mathrm{I} i+\mathrm{b} \hat{\mathbf{c}}+\mathrm{di}+\text { fêlêla }+\mathrm{fao} \\
& \mathrm{I}) \mathrm{i}+\text { fồla + fao }
\end{aligned}
$$

Sometimes the subjectival concord in the initial position occurs in the consecut ive form tsa. Synonymous verbs for/p̈la are also used, like êma/stop; fela/ passed. The subjectival concord di probably recalls the noun dikgang which means things/story/plot.

\subsection{FUNCTIONS FULFILLED BY OPENING AND CLOSING FORMULAE}

Opening and closing formulac fulfil several functions when folktales are told. These functions must be viewed against the background of the whole narrating process namely the narrator, situation, audience and the tradition. The following functions can be fulfilled by them:

\subsection{Guides the andience into a fictitious world}

According to Sutherland and Arbuthnot (1965:150) the formulac lead the audicnce into and out of a fictitious world. They say:

"Such folktale conventions do more than convey an idea of long ago, they carry the reader at once to a dream world where anything is possible".

During firldwork, collecting T'swana folktales, this was definitcly found to be the case.

Bascom (1965:6) cven stresses this point further by saying that this formula warns the audience that the tale that follows is fictitious and must not be 
believed to be true.

\subsection{Link the narration with the audience}

The opening and closing formulac are responsible for a certain attitude between the audience and the narrator. Finnegan (1970:380) describes it as follows:

"Conversely the opening formulac serve to rouse the interest of the audience, sometimes cliciting a formal response: from them as well as sctting the mood for the start of the narration."

While collect ing Tswana folkt ales this was recognized. The audience talked spont aneously about their daily task but their attention was immediately drawn when hearing the opening formula. When the narrator ends his folktale by the closing formula the connection between narrator and audience ends. They immediately start discussing the folktale and the narration by the narrator.

This point is also stressed by Scheub (1975:15):

"The creator of a ntsomi must thus bring the altention and imagination of the audience into total involvement in the production."

\subsection{Defines the limits of the folktale}

Finncgan (1970:387) and Scheub (1975:9-13) states the fact that the formulac serve as boundaries for a folktale and the narrative process. This is also the case in Tswana folktales.

\subsection{Distinguishing function}

It serves as a framework to distinguish different forms of folktales from each other. It also sets folktales apart from normal conversation and from other forms of serious discourse.

No cvidence has been found in Tswana that the formulae serve as a framework to creatc a dist inction between the different forms of folkt ales. It definitcly sets folktales apart from other forms of conversation and discourse. 


\subsection{The opening formulae focus on the characters and action in the folktale}

Sutherland and Arbuthnot (1965:153) describe it as follows:

"The introduction to a folktale does exactly what its name implies. It introduces the reader to the leading characters."

The opening formulac also outline the situation in which the characters find themselves.

Examples:

E kilê ga bô go na le monna le mosadi, ba agilê motse wa bônê o montlê.

Once upon a time there were $a$ man and a woman (characters) with a nicely built home (situation).

Ga twe ekilè ya re e le Mosetsana a bidiua Nopolole, a na le monnaawê.

It is said there was a litlle girl called Nopolole (character) who had a litlle sister (situation).

\section{CONCLUSIONS}

Folktales arc constructcd by various parts namely words, sentences, refrains and as discussed above also opening and closing formulae. These elements are necessary to construct folktales and when they are well structured they contribute a grcat dcal to the success of folktales. Especially the opening and closing formulac fulfil a characteristic role in the folktales.

Tsa bê di hêla!

It came to an cnd!

\section{BIBLIOGRAPHY}

BASCOM, W.R. 1965. "The forms of folklore: Prose narratives" in .7ournal of American folklore, 78, pp. 3-19.

FINNEGAN, R. 1967. Limba stories and storytelling. Oxford, Clarendon Press.

FINNEG $A N$, R. 1970. Oral literature in $\Lambda$ frica. Oxford, Clarendon Press. GUMA, S.M. 1967. The form, content and technique of traditional literature in Southern Sotho. Pretoria, Van Schaik.

MARIVATE, C.T.D. 1973. Tsonga folktales: form, content and delivery. MA, Unisa. 
MBITI, J.S. 1966. Akamba stories. Oxford, Clarendon Press.

NEETHLING, S.J. 1979. Dic Xhosa int somi: 'n strukturele behandeling. D.Litt. Stellenbosch.

SCHEUB, H. 1975. The Xhosa intsomi. Oxford, Clarendon Press.

SUTHERLAND, X. \& ARBUTHNOT, M.H. Children and books.

Glenview III, Scott; Foresman \& Co.

SWANEPOEL, S.A. 1982. Die Tswanavolksverhaal. D.Litt. et Phil. Unisa. 